\title{
Company-provided further training in Germany and the Netherlands
}

\author{
Piet Allaart ${ }^{a}$, Lutz Bellmann ${ }^{b, *}$, Ute Leber ${ }^{c}$ \\ ${ }^{a}$ OSA Institute for Labour Studies, Tilburg, Netherlands \\ ${ }^{b, c}$ Institute for Employment Research, University of Erlangen-Nuremberg
}

\begin{abstract}
This study investigates the impact of determining factors of firms' further training activities from a cross-country perspective. Since the differences in the institutional background of training are of special interest we choose the Netherlands and Germany. Using the IAB (German) and OSA (Dutch) establishment panels we are able to control for additional differences in country-specific labour market institutions, the personnel structure, the firm structure and technology. Holding everything else constant the firms' engagement in further training in the Netherlands is much higher than in Germany, especially in SME and with respect to older workers.
\end{abstract}

Keywords: further training, firm-sponsored training, comparative studies of countries

\section{Introduction}

Globalisation, technological/organizational change and demographic development tend to increase the demand for skilled relative to unskilled labour. Therefore not only the EU has agreed in its Lisbon strategy to increase the participation in continuous training of employees in order to sustain their employability and increase the competitive strength of the firms ${ }^{1}$. However, some European countries evidently have severe problems to achieve the ambitious goals set by the EU, while others can be regarded as very successful in the field of further training.

According to the Continuing Vocational Training Survey (CVTS) ${ }^{2}$, the European survey on company-provided training, the proportion of enterprises providing training was clearly above-average in the Northern European countries (Denmark, Sweden, Norway, Finland) and the Netherlands in 1999, while it was rather low in

\footnotetext{
${ }^{*}$ Corresponding author: Institute for Employment Research, Regensburger Str. 104, 90478 Nuremberg, Germany. E-mail: lutz.bellmann@iab.de. Telephone: +49-911-1793046. The authors thank two anonymous referees and the editor for their valuable comments and suggestions.

${ }^{1}$ In the Lisbon strategy, the European commission and the member states agreed five European benchmarks concerning the quality of and the access to education and training. One of these benchmarks provides for an increase in the average participation of working adults population in lifelong learning by at least $12.5 \%$ until 2010.

${ }^{2}$ For more information on the CVTS, see section 3.
} 
the Southern European countries (Spain, Portugal, Italy). Germany reached the $9^{\text {th }}$ position within the EU-25 in 1999; the Netherlands, in contrast, held the $3^{\text {rd }}$ position behind Denmark and Sweden. Concerning the participation rates in further training, Germany's rank among EU member states was with $32 \%$ on the $11^{\text {th }}$ place, whereas the Netherlands have reached the $8^{\text {th }}$ position in the same survey with a participation rate of $41 \%$ (Nestler \& Kailis, 2002).

Looking at these remarkable differences in the firms' engagement in further training, it seems to be interesting to ask for the reasons why the companies' further training activities are higher in some countries than they are in others. In this paper, we want to compare the training situation in German establishments with the one in Dutch establishments. There are mainly two reasons for choosing these two countries: On the one side, the level of further training differs markedly between Germany and the Netherlands - with the Netherlands belonging to the top group of training countries within Europe. On the other side, there are some important differences in the institutional background of training in both countries - in particular according to training participation of certain groups like older employees or small and medium sized enterprises (SMEs) - and it seems to be interesting to analyse the way these institutional differences affect the firms' engagement in training ${ }^{3}$.

There is a lack of empirical studies investigating the impact of determining factors of firms' further training activities from a cross-country perspective. In order to carry out such an analysis, it is necessary to have comparable datasets for the countries included. We are not aware of any international datasets which allow to investigate the determinants of further training within a broad analytical framework (for an overview of empirical studies see Bellmann, 2001). However, for the Netherlands and Germany, we can use establishment data which is comparable for both countries.

The purpose of our paper is to provide an overview of the institutional background of further training in Germany and the Netherlands, to present empirical results on further training, and to compare the determinants of training in both countries. The paper is organized as follows: In section 2, we describe the institutional background of further training in Germany and the Netherlands. In section 3, the data and some descriptive results on training in the two countries are presented. In section 4 , we analyse the factors influencing the provision of training in both countries. Section 5 summarizes the results and draws some conclusions.

\footnotetext{
${ }^{3}$ For a comparison of the firms' further training behaviour in Germany and Denmark, see Haak (2003). For an overview of the institutional background of further training in several countries, see Expertenkommission (2005).
} 


\section{The institutional background of further training in Germany and the Netherlands}

In Germany as well as in the Netherlands, continuing training is, to a large extent, privately organised and funded. However, there are some striking differences in the framework conditions between both countries - which should have an effect on the incidence and intensity of further training in the respective country.

In Germany, further training for the employed is characterized by a minimal degree of regulation by the state. While further training of the unemployed is organised by the Federal Employment Agency, the private sector (in particular companies, but also individuals) plays the dominant role in providing continuing training for the employed. In contrast to the field of initial vocational training, there is no legal framework which regulates the contents, financing and structures of further training. Existing laws deal with educational leaves of the employed, for example, but it is mainly up to the employers/ employees to organize and finance training activities. Some collective agreements deal with further training, but these agreements are rather exceptions than the rule and their influence on further training is supposed to be small (Moraal \& Schönfeld, 2005; Haak, 2003).

In the Netherlands, in contrast, collective labour agreements play an important role in providing and financing further training (for an overview see Moraal \& Schönfeld, 2005; Maes, 2004 or Waterreus, 2002). Financial arrangements in collective agreements are made through funds which are intended to keep the skills and competences of personnel in a certain branch at a high level. The most prominent of these funds are the training and development funds (O\&O-Funds) which are financed through a levy on the gross wage bill of the firms in the respective sector. Training is often provided by sector-specific training institutions and linked to an accreditation system for training institutes. In some sectors, there are special arrangements made for specific target groups, such as women, low-skilled employees or migrants. Most of the training funds are focussed on formal (i.e. internal and external) training courses - even though some of them acknowledge workplace-related forms of training also. In 2002, there were 99 O\&O-Funds which covered about $40 \%$ of all employees, including employees of SMEs.

Apart from those training funds, the Dutch Government introduced a new tax law in 1998, which gives companies the opportunity of three forms of additional tax deductions for their training expenditures. The first deduction is intended to stimulate training participation in general. The second deduction is meant to stimulate training in small- and medium-sized firms. The third form of deduction, finally, aims at enhancing the training participation of older employees (Leuven \& Oosterbeek, 2004).

What can we conclude from these considerations? Firstly, we can suppose that the higher incidence of training in the Netherlands has to do at least partly with the specific framework conditions in this country. Secondly, we should expect that there are not only differences in the overall level of training between both countries, but 
that there also cross-country differences in the training engagement of certain groups of employers and employees - in particular SMEs and older workers. Thirdly, we suppose that there may be cross-country differences concerning the form of training provided (formal - informal/ work-related further training). The way the training behaviour of Dutch and German firms differ within these aspects will be analysed in the following sections.

\section{Data and empirical results}

In Germany as well as in the Netherlands, there are several surveys on the enterprise or establishment level which provide information on further training. For our purpose, we will use two datasets. In a first step, we will present results on further training from the CVTS 2. The CVTS is a European survey which was designed to measure the structure of further training activities provided by employers; it covers enterprises in the private sector with at least ten employees ${ }^{4}$. The second survey CVTS 2 - was carried out in 2000, with 1999 as reference period. In a second step, we will present results from two comparable surveys on the establishment level in Germany and the Netherlands, the IAB- and the OSA-Establishment Panel. We will refer to the 1999 data because these are the best comparable for both countries.

\subsection{Results from the CVTS}

Information on the offer of and the participation in further training provided by CVTS 2 for the year 1999 is presented in table 1. The table shows that the percentage of enterprises providing training is higher in the Netherlands (88\%) than in Germany $(75 \%)$. Furthermore, we can see that training engagement is higher in large and medium-sized enterprises than in small enterprises - in both countries. However, while almost all German and Dutch firms with 250 or more workers provide some form of training, the percentage of SMEs providing training is significantly higher in the Netherlands than in Germany. The higher training engagement of Dutch firms in general might be a result of the specific institutional framework conditions in the Netherlands depicted in section 2 (collective training arrangements, tax deductions). These framework conditions may also explain the higher percentage of small and medium-sized training enterprises in the Netherlands because Dutch SMEs are given special incentives to invest in further training.

Furthermore, the difference in training incidence is concentrated on the provision of internal and external courses. For the other (work-related) forms of training, the German percentage of training enterprises is slightly higher. A possible explanation might be that most of the Dutch training funds are focussed on formal (i.e. internal and external) training courses and that only the expenditures for formal further training are qualified for tax deduction (Leuven \& Oosterbeek, 2004). Both rules might

\footnotetext{
${ }^{4}$ Results are published in Nestler \& Kailis (2002).
} 
Table 1: Results of the European Continuing Vocational Training Survey (CVTS) 1999 , private sector, 10 or more employees.

\begin{tabular}{|c|c|c|c|}
\hline & & Germany & Netherlands \\
\hline$\%$ firms & ith training & 75 & 88 \\
\hline of which & 10-49 employees & 71 & 85 \\
\hline & 50-249 employees & 87 & 96 \\
\hline & 250 or more employees & 98 & 98 \\
\hline$\%$ firms $\mathrm{w}$ & th internal or external courses & 67 & 82 \\
\hline$\%$ firms $\mathrm{w}$ & th other forms of training & 72 & 70 \\
\hline Participa & on rate, in \% (all firms) & 32 & 41 \\
\hline of which & 10-49 employees & 25 & 36 \\
\hline & 50-249 employees & 27 & 42 \\
\hline & 250 or more employees & 35 & 43 \\
\hline Participa & on rate, in $\%$ (training firms) & 36 & 44 \\
\hline of which & 10-49 employees & 39 & 46 \\
\hline & 50-249 employees & 33 & 45 \\
\hline & 250 or more employees & 37 & 43 \\
\hline
\end{tabular}

Source: Eurostat

increase the Dutch firms' incentive to invest in formal rather than in informal further training.

There is not only a higher share of training enterprises in the Netherlands than in Germany, but also a higher participation rate in training. This applies to the participation rate using the employees of all firms as reference, but also to the participation rate within the firms offering training. Looking at the participation rate in all companies, the proportion of employees taking part in further training increases with firm size - in Germany as well as in the Netherlands. The participation rate in each size class is higher in the Netherlands than in Germany, but the differences are more pronounced in the case of SMEs. However, this is also a result of the higher share of SME providing training in the Netherlands - and not only the effect of a higher training intensity within these firms. If only training firms are considered, the differences between both countries remain - but they are less strong than in the case of the participation rates in all firms. However, in this case, Dutch and German SME show a slightly higher participation rate than larger firms do. 


\subsection{Results from the IAB- and OSA-Establishment Panel}

In contrast to the CVTS, the IAB (German) and OSA (Dutch) establishment panels ${ }^{5}$ do not only look at the firms' further training behaviour, but they provide comparable information on a large number of variables. Their goal is to provide detailed information about the demand side of the labour market. Therefore, questions on the employees, changes in employment and the structure of qualifications constitute a big part of the questionnaire. Some further questions deal with apprenticeship and further training, and developments in business and investment. The explicit wording of the questions dealing with further training in both surveys is documented in the appendix.

While CVTS provides information on enterprises, the sample units of the IAB and the OSA-Panels are establishments. Further differences are that the IAB- and OSA-data include establishments with five up to ten employees, and that all economic sectors (including the public sector) are represented. Besides, the following section will provide information on formal further training (internal - external courses) only whereas the CVTS-data mentioned in the previous section referred to formal and informal further training.

In order to make the IAB-and the OSA-Panels comparable, we dropped all establishments with less than five employees from the IAB-data because the OSA-Panel does not include these establishments. Another selection was made by restricting the German data to former West-Germany. A remaining difference between both datasets is the period of observation. While in the IAB-panel, the questions on training refer to the first half of the year, in the OSA-panel, they cover the whole preceding year. Therefore, the percentages of establishments providing training as well as the participation rates in training cannot be compared between both countries ${ }^{6}$. That is why we will not present absolute levels of training in the following tables but standardised results. The standardisation was done by equating the training engagement of the establishments with 250 and more employees with 100 in both countries and relating the firms' training engagement within the other size classes to this reference category. By doing so, it is not possible to compare the absolute levels of training between Germany and the Netherlands, but the structure of training within several segments. In the regression analyses, the different reference periods could be a problem if there were some German firms which offer further training not continually, but only during certain periods of the year (namely in the first or the second half of the year). Such a discontinuous engagement in further training might be found particularly in smaller firms. Since small establishments are not included in our analyses, we expect that the differences in the observation period do not affect our econometric results.

Table 2 provides information on the provision of training. It confirms the out-

\footnotetext{
${ }^{5}$ See Kölling (2000) for more information on the IAB-Establishment-Panel and Fouarge et al. (2001) on the OSA-Panel.

${ }^{6}$ The IAB-figures cannot be multiplied by 2 , as a rough estimate, because many workers participate in more than one course during the year.
} 
come of CVTS that small and medium-sized German establishments are less likely to train than their Dutch counterparts. As we can distinguish between internal and external courses, we can see that the difference between both countries is more prevalent in external courses.

Table 2: Standardised results for size-classes of the proportion of establishments with internal or external courses ( 250 or more employees $=100$ ), 5 or more employees

\begin{tabular}{lcccccc}
\hline & \multicolumn{3}{c}{ Germany } & \multicolumn{3}{c}{ Netherlands } \\
\hline & internal & external & $\begin{array}{c}\text { internal } \\
\text { or external }\end{array}$ & internal & external & $\begin{array}{c}\text { internal } \\
\text { or external }\end{array}$ \\
250 or more & 100 & 100 & 100 & 100 & 100 & 100 \\
$100-199$ & 78 & 85 & 90 & 72 & 97 & 98 \\
$50-99$ & 67 & 82 & 87 & 53 & 85 & 91 \\
$20-49$ & 49 & 65 & 72 & 46 & 80 & 87 \\
$10-19$ & 33 & 46 & 53 & 32 & 65 & 74 \\
$5-9$ & 15 & 34 & 36 & 18 & 49 & 55 \\
\hline All size- & 29 & 45 & 50 & 36 & 68 & 74 \\
classes & & & & & & \\
\hline
\end{tabular}

Source: IAB, OSA

The results for training participation rates are presented in table 3 which shows large differences between both countries. If only training establishments are included, the participation rates in Germany decrease with establishment size. If also non-training establishments are considered, the differences between size-classes are relatively small. In the Netherlands, the participation rates are more or less independent of size if only training establishments are included. For all establishments, participation rates increase with size, because of the lower training incidence of small establishments.

Table 3: Standardised results for size-classes of the participation rates in internal or external courses ( 250 or more employees $=100$ ), 5 or more employees

\begin{tabular}{lcccc}
\hline & \multicolumn{2}{c}{ Germany } & \multicolumn{2}{c}{ Netherlands } \\
\hline & $\begin{array}{c}\text { All estab- } \\
\text { lishments }\end{array}$ & $\begin{array}{c}\text { Training } \\
\text { establishments }\end{array}$ & $\begin{array}{c}\text { All estab- } \\
\text { lishments }\end{array}$ & $\begin{array}{c}\text { Training } \\
\text { establishments }\end{array}$ \\
250 or more & 100 & 100 & 100 & 100 \\
$100-249$ & 91 & 103 & 94 & 96 \\
$50-99$ & 107 & 126 & 82 & 90 \\
$20-49$ & 117 & 159 & 80 & 100 \\
$10-19$ & 104 & 190 & 77 & 103 \\
$5-9$ & 95 & 237 & 53 & 98 \\
\hline All size-classes & 102 & 128 & 87 & 96 \\
\hline
\end{tabular}

Source: IAB, OSA 


\section{Determining factors of further training in Germany and the Netherlands: similarities and differences}

\subsection{Hypotheses}

In the preceding section, we showed that there are differences in the training behaviour of Dutch and German firms - concerning the level of training, but also its structure, in particular by firm size. In the following, we will have a closer look on the factors influencing the firms' training decision and ask whether these factors are the same in both countries or not.

For Germany and the Netherlands as well as for other countries, there are several empirical studies investigating the training decision of firms and individuals (for studies on the enterprise/ establishment level see for example Bellmann \& Leber, 2006 (Germany), Gerlach \& Jirjahn, 2001 (Germany), for studies on the individual level see Büchel and Pannenberg, 2004 (Germany), Leuven \& Oosterbeek, 2004 (Netherlands) or Arulampalam et al., 2004 (several European countries)). Following these studies, we will analyse the potential influence of the following factors on training:

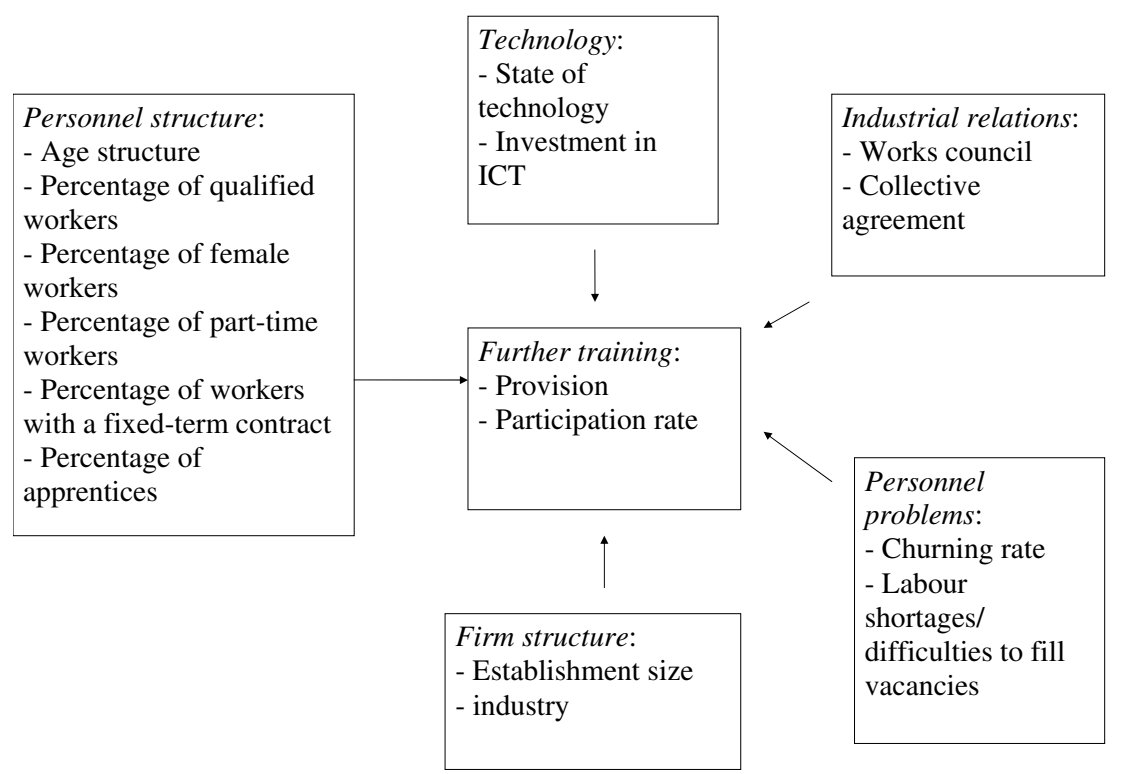

Figure 1: Determinants of further training

For some of these variables, we expect a similar effect for both countries. Looking at technology, for example, it is a well known result that the introduction of new 
technology acquires new competences and therefore goes along with a higher engagement in training (e.g., Gerlach \& Jirjahn, 2001). A higher share of qualified employees should go along with a higher engagement in training - in Germany as well as in the Netherlands. Furthermore, we do not find any reasons why the effects of churning or the number of workers with fixed-term contracts should differ between Germany and the Netherlands. From a theoretical point of view, however, the effect of these variables on training is undefined: While human capital theory (Becker, 1964) suggests that the firms' incentive to invest in training is smaller in the case of a high share of employees with a fixed-term contract and a high churning or quit rate, there are also arguments which suggest a positive relationship between these variables and further training ${ }^{7}$.

The effect of other variables on training, in contrast, might differ between both countries. Against the institutional background of further training depicted in section 2 , there might be differences with respect to the age structure of the workforce and firm size. Several empirical studies show that older employees are less likely to participate in further training than are their younger counterparts (for an overview of several empirical studies for Germany see Bellmann, 2003). However, since the Dutch Government provides incentives for firms to invest in the human capital of older employees, the share of older employees does not necessarily have to affect the firms' training engagement negatively in the Netherlands. Furthermore, there may be differences with respect to firm size: Even though larger firms in Germany and the Netherlands should be more likely to be engaged in training than smaller firms, the relationship between the number of employees and the provision of training might be less pronounced in the Netherlands.

Apart from these differences in the institutional background of further training, there are some additional differences in country-specific labour market institutions which may also affect the firms' training decision. First of all, the status of the apprenticeship system is different in both countries. From a theoretical point of view, firms can meet their specific demand for skills not only by hiring employees from the external labour market, but also by providing apprenticeship and/ or further training. While firms in which occupations dominate that demand a great deal of theoretical knowledge might have a preference for hiring employees having attended full-time education, establishments where occupations require practical skills might have a preference for apprenticeship or further training (Smits \& Zwick, 2004). In this sense, both types of education should be complements. In these human-capitaloriented firms, one should find a positive correlation between both types of training. Furthermore, apprenticeship training as well as further training might be strategies to meet a lack of skilled workers. Therefore, it can be expected that firms which

\footnotetext{
${ }^{7}$ In this sense, fixed-term contracts can be used as a probation period, and the employer can use the training result as a screening device. Booth and Zoega (1999) develop a model that predicts a positive relationship between the quit rate and the number of workers trained. The basic idea is that a higher quit rate makes the firm less interested in the level of workers' productivity in the future, and may therefore stimulate the provision of training. Autor (2001) argues that temporary help firms provide free general skills training in order to elicit private information about worker ability.
} 
have difficulties in finding qualified labour invest in both, apprenticeship training and further training.

Turning the attention to the systems of apprenticeship training in Germany and the Netherlands, we can mention that apprenticeship training is a highly valued form of vocational education in Germany and that the majority of employees acquired their skills during their period of apprenticeship. In the Netherlands, in contrast, the apprenticeship training system is also well developed but of less importance than it is in Germany (Smits \& Zwick, 2004). It is often a possibility for young people with little learning abilities to get a vocational education (Frietman \& Hövels, 1997). The effect of apprenticeship training on further training should depend on its specific status in both countries. Since the Dutch system of vocational education is at a less advanced level of qualification than the German system, it might be the case that Dutch apprentices need to receive more further training than German apprentices do.

Secondly, there are cross-country differences in the systems of co-determination. In Germany and the Netherlands, works councils can negotiate further training issues (e.g., selection of training participants, arrangement of training courses), but the institutions for co-determination differ between both countries: On the one side, German works councils have a stronger legal base; on the other side, Dutch establishments with ten to 35 employees can have only advisory personnel meetings, but not in a comparable institutionalised manner as in Germany. Due to these differences, we expect a stronger influence of works councils on personnel policies (including further training) in Germany than in the Netherlands (see also Bauernschuster, Falck \& Heblich (2008) for the relationship between further training and works councils in Germany).

Thirdly, there are cross-country differences in the impact and structure of parttime work. From a theoretical point of view, a high share of part-time workers should exert a negative effect on further training - which should be stronger in the case of a low number of working hours ${ }^{8}$. When comparing the potential influence of this variable on training between Germany and the Netherlands, the specific part-time culture in both countries has to be considered. In the Netherlands, part-time jobs are much more widespread than in Germany. While in Germany, part-time is mainly concentrated on women, there is also a relatively high share of men working part-time in the Netherlands. Since the number of working hours is rather high for them, there should be a higher incentive to participate in further training. Furthermore, it can be supposed that the (negative) relationship between part-time work and training is less pronounced in the Netherlands - what can be explained with the greater importance and maybe acceptance - of this kind of work in this country.

\footnotetext{
${ }^{8}$ However, the empirical evidence on the correlation of part-time and participation in training is ambiguous. While there seem to be a "part-time"-effect on training on the basis of establishment data (e.g., Bellmann \& Leber, 2006), empirical studies on the basis of individual data for Germany (e.g., Büchel \& Pannenberg, 2004) show that part-time (as well as sex) per se cannot explain the lower participation rate of women, but that rather the marital status and the number of children play a role.
} 


\subsection{Econometric results}

In this section we present the results of multivariate analyses in which we investigate the determining factors of employer-provided further training. In a first step, we estimate the firms' decision whether to offer further training to their employees or not. This is done by using a probit model with the provision of further training as the dependent variable. The results of the probit analyses are presented in the appendix. In a second step, we estimate the participation in further training by using a tobit model. In the tobit model presented in this section of the paper, we included all establishments (i.e., establishments with and without further training activities). Hence, this analysis combines the effect of the participation rates in training-providing establishments and the probability that establishments offer training courses ${ }^{9}$. In addition, we also estimated a tobit model in which we included the training firms only. Since the results of the tobit estimations including all establishments/ training establishments only are very similar, we refrained from presenting both of them. Furthermore, it can be seen that the results of the tobit and the probit estimations are quite similar. This indicates that the decision whether to train or not as well as the decision about the number of training participants are affected by (almost) the same variables similarly.

The results show that most of the variables characterizing the personnel structure exert a significant influence on the participation in further training. However, there are some interesting differences between Germany and the Netherlands:

While we find a strong significant negative relationship between the share of older employees and participation in training for Germany, there is no significant effect in the Netherlands. This might be the result of the specific institutional framework in the Netherlands. There are not only cross-country differences with respect to the oldest but also to the youngest age group. While the respective coefficient is not significant in Germany, there is a negative impact in the Netherlands. A possible explanation might be that young students work more often in the Netherlands, mostly in simple jobs that need no specific training. It must be noted, however, that this group is relatively small and that the Dutch result is only significant at the 5\%-level.

A higher share of qualified employees is positively related with participation in training, which is a common result in the existing literature. We see a highly significant and equal coefficient for both countries.

For both countries the relationship between the share of female workers and participation in training is positive. This might indicate that female workers do not participate less in training than their male counterparts. Arulampalam et al. (2004) found the same for the Netherlands and several other European countries. As many women work part-time, this is partly compensated by a lower participation of parttime workers. A general conclusion is that if women participate less often in further training than men, this seems to be rather a part-time- than a gender-effect. While both categories of part-time work have a strong, negative effect on further training in

\footnotetext{
${ }^{9}$ We did not succeed in finding a variable which has a significant impact on the firms' decision to train but not on their training intensity. Therefore, we were not able to solve the (potential) sample selection problem by using appropriate econometric methods (see Wooldridge, 2002).
} 
Table 4: Tobit-estimates for participation rates in internal and / or external courses (including establishments without training activities), 1999, 5 or more employees

\begin{tabular}{|c|c|c|}
\hline \multirow{3}{*}{$\%$ age $<20$} & Germany & Netherlands \\
\hline & 0.007 & $-0.268 *$ \\
\hline & $(0.099)$ & $(0.144)$ \\
\hline \multirow[t]{2}{*}{$\%$ age $20-30$} & 0.048 & $0.159 * *$ \\
\hline & $(0.056)$ & $(0.074)$ \\
\hline$\%$ age $30-40$ & reference & reference \\
\hline \multirow[t]{2}{*}{$\%$ age $40-50$} & 0.072 & $0.178 * *$ \\
\hline & $(0.055)$ & $(0.077)$ \\
\hline \multirow[t]{2}{*}{$\%$ age $50-65$} & $-0.180 * * *$ & 0.066 \\
\hline & $(0.050)$ & $(0.083)$ \\
\hline \multirow[t]{2}{*}{$\%$ qualified workers } & $0.180 * * *$ & $0.176^{* * *}$ \\
\hline & $(0.021)$ & $(0.038)$ \\
\hline \multirow[t]{2}{*}{$\%$ female } & $0.172 * * *$ & $0.223^{* * *}$ \\
\hline & $(0.023)$ & $(0.051)$ \\
\hline \multirow[t]{2}{*}{$\%<15(12)$ hours per week } & $-0.218 * * *$ & $-0.276 * * *$ \\
\hline & $(0.052)$ & $(0.082)$ \\
\hline \multirow[t]{2}{*}{$\%$ 15-24 (12-23) hours per week } & $-0.194 * * *$ & -0.106 \\
\hline & $(0.047)$ & $(0.069)$ \\
\hline \multirow[t]{2}{*}{$\%$ fixed term contracts } & 0.042 & -0.035 \\
\hline & $(0.050)$ & $(0.095)$ \\
\hline \multirow[t]{2}{*}{$\%$ apprentices } & 0.055 & $0.481 * * *$ \\
\hline & $(0.086)$ & $(0.116)$ \\
\hline \multirow[t]{2}{*}{ Technological advanced (yes/ no) } & $0.061 * * *$ & 0.029 \\
\hline & $(0.012)$ & $(0.020)$ \\
\hline \multirow{2}{*}{$\begin{array}{l}\text { ICT-investment or new technology introduced (yes/ } \\
\text { no) }\end{array}$} & $0.100 * * *$ & $0.054 * *$ \\
\hline & $(0.012)$ & $(0.022)$ \\
\hline \multirow{2}{*}{$\begin{array}{l}\text { Expected labour shortages or difficulties to fill } \\
\text { vacancies (yes/no) }\end{array}$} & $0.036 * * *$ & 0.026 \\
\hline & $(0.011)$ & $(0.021)$ \\
\hline \multirow[t]{2}{*}{ Churning rate } & -0.014 & 0.082 \\
\hline & $(0.013)$ & $(0.056)$ \\
\hline \multirow[t]{2}{*}{ Collective agreement (yes/ no) } & $0.058 * * *$ & -0.003 \\
\hline & $(0.014)$ & $(0.036)$ \\
\hline \multirow[t]{2}{*}{ Works council (yes/ no) } & $0.071 * * *$ & $0.096 * * *$ \\
\hline & $(0.015)$ & $(0.024)$ \\
\hline \multirow[t]{2}{*}{ Size $(\ln )$} & $-0.014 * * *$ & $0.017 *$ \\
\hline & $(0.005)$ & $(0.009)$ \\
\hline Sector dummies & yes & yes \\
\hline \multirow[t]{2}{*}{ Intercept } & $-0.119 * * *$ & $-0.167 * *$ \\
\hline & $(0.040)$ & $(0.072)$ \\
\hline $\mathrm{N}$ & 3671 & 1419 \\
\hline Pseudo- $\mathrm{R}^{2}$ & 0.175 & 0.173 \\
\hline
\end{tabular}


Germany, we only find a significantly negative effect of the proportion of part-time workers with few working hours in the Netherlands. This finding might have to do with the specific "part-time-culture" in the Netherlands where part-time work is of a much greater importance as it is in Germany.

There is a positive relationship between the participation rate in further training and the number of apprentices, albeit not significant for Germany. However, in this country the probability that an establishment has external courses for its workers is - in agreement with the Dutch situation - positively related to the number of apprentices. The fact that relatively more Dutch workers receive further training may be attributed to the specific characteristics of the Dutch system of vocational education which is more basic and requires more further training than the German apprenticeship system.

For fixed term contracts we find no significant relationship with training. The negative effect that it is not profitable for employers to invest in temporary workers is outweighed by positive effects. As fixed term contracts are often used as a probation period, workers can be motivated to participate in training, and employers can use this as a screening device.

As expected, participation in further training is higher in establishments that invested in ICT or introduced a new technology - a result that can be found for both countries. Firms confronted with (expected) labour shortages, in contrast, are more engaged in training in Germany only. Regarding the churning rate we do not find a significant effect on training participation. Several factors with opposite effects play a role (Booth \& Zoega, 1999).

Bargaining institutions seem to be relevant. In Germany, collective agreements as well as works councils are positively related to the participation in further training. For the Netherlands we find this for the works councils only. This may be surprising, because training is often part of collective agreements. But this is certainly not an exclusive relationship. All in all we can conclude that in both countries, a strong influence of workers or their representatives is positively related to training participation, a result that was also found by Böheim \& Booth (2004) for Britain.

Finally, establishment size influences the probability that at least one worker takes part in training. The larger the establishment, the higher is this probability (see appendix). In Germany this effect is more than offset by the fact that in larger establishments relatively fewer workers participate in training. This is in line with tables 2 and 3. In the Netherlands, participation rates by size-class do not differ too much, so that a positive effect on participation results.

\section{Summary and conclusions}

Global and technological developments have stressed the importance of a highly qualified workforce in EU-countries. Apart from a good educational system for young people, further training is seen as very important. Training participation differs between countries. In this paper, we concentrated on differences between Ger- 
many and the Netherlands. On the one side, there are cross-country differences in the overall level of training as well as in the training participation of certain groups. On the other side, there are some important differences in the institutional background of training - which can explain at least a part of the differences in the training behaviour of Dutch and German firms.

Our main findings we derived from the European training survey CVTS and Dutch and German establishment-panel data can be summarised as follows:

- There is a marked difference in the overall level of training between Germany and the Netherlands. While the firms' engagement in formal further training is much higher in the Netherlands than it is in Germany, there is a slightly higher percentage of firms providing work-related forms of training in Germany than in the Netherlands.

- There are differences in the training engagement of Dutch and German SMEs. Even though in both countries, larger firms are more engaged in training than SMEs, the share of Dutch SMEs providing training is much higher than the respective share of German SMEs.

- A high share of older workers does not go along with a low training participation rate in the Netherlands. In Germany, in contrast, participation in further training is lower in establishments with a high share of older employees.

- There are differences with respect to the apprenticeship system and part-time work. On the one side, we find a positive correlation between the share of apprentices and the share of further training participants for the Netherlands only. On the other side, the percentage of part-time workers (with a higher number of working hours) is negatively correlated with the participation in further training in Germany only.

Against the background of these results, what can we conclude from these findings?

Firstly, we can see that the institutional setting seem to have an essential influence on the firms' decision whether to train their employees or not. While the German further training system is characterised by a minimal degree of regulation, there are regulations concerning training on the level of the state and collective agreements in the Netherlands. These framework conditions seem to have an influence on the overall level of training in the Dutch firms, but also on the training participation of SMEs and older employees. In the Netherlands, the institutional background of training is characterised by funds on the level of collective agreements and the option of additional tax deductions. Other (training-intensive) countries like Sweden or Denmark have a different institutional background. It is not the aim of our paper to compare the training institutions of several countries and to judge which one is the best. All we want to conclude is that a higher involvement in further training (of all 
firms but also of certain groups) can be reached by creating a favourable institutional setting.

However, when analysing the way institutions affect training, it has to be considered that there may be biases in favour of one kind of training and at the expense of another form of training. As CVTS-data shows, the Dutch enterprises are quite "successful" in providing formal forms of training, whereas the percentage of enterprises providing informal, work-related forms of training is slightly higher in Germany. This might have to do with the specific regulations in the Netherlands which support formal further training mainly. It concludes that it is not sufficient to make cross-country comparisons of one form of training only - but it is rather necessary to regard several types of further training.

Finally, it became obvious that it is necessary to take account of differences in labour market institutions which are not directly related to further training. On the one side, there are differences in the German and Dutch systems of initial vocational education. Assuming that the German apprenticeship system delivers higher qualified workers than the Dutch system does, it can be concluded that the lower German participation in further training deserves partly a positive judgement. On the other side, our results concerning part-time work indicate that not only cost-benefit criteria affect the firms' decision to train their employees or not, but that also the impact and acceptance of certain groups of employees play a role in this context.

\section{References}

Arulampalam, W., Booth, A.L. \& Bryan, M.L. (2004). Training in Europe. Journal of the European Economic Association, 2 (2), 346-360.

Autor, D. H. (2001). Why do temporary help firms provide free general skills training?. The Quarterly Journal of Economics, 116(4), 1409-1448.

Bauernschuster, S., Falck, O. \& Heblich, S. (2008). The Impact of continuous training on a firm's innovation. CESifo Working Paper No. 2258.

Becker, G.S. (1964). Human Capital. A theoretical and empirical analysis, with special reference to education. New York: National Bureau of Economic Research.

Bellmann, L. (2003). Datenlage und Interpretation der Weiterbildung in Deutschland. Bielefeld: Bertelsmann.

Bellmann, L. (2001). Vocational training research on the basis of enterprise surveys: An international perspective. In P. Descy \& M. Tessaring (Eds.) Training in Europe. Second report on vocational training research in Europe 2000: Background report, Volume 2. Luxembourg: Bernan Associates.

Bellmann, L. \& Leber, U. (2006). Weiterbildung in KMU. In M. Weiß (Ed.) Evidenzbasierte Bildungspolitik: Beiträge der Bildungsökonomie. Berlin: Duncker \& Humblot.

Boheim, R. \& Booth, A.L. (2004). Trade union presence and employer-provided training in Great Britain. Industrial relations: A Journal of Economics and Society, 43 (3), 520-545.

Booth, A.L. \& Zoega, G. (1999). Do quits cause under-training?. Oxford Economic Papers, 51, 379-386.

Büchel, F. \& Pannenberg, M. (2004). Berufliche Weiterbildung in West- und Ostdeutschland: Teilnehmer, Struktur und individueller Ertrag. Zeitschrift für Arbeitsmarktforschung, 37(2), 73-126.

Expertenkommission Finanzierung Lebenslangen Lernens (2005). Der Weg in die Zukunft. Bielefeld: Bertelsmann

Fouarge, D.J.A.G., Kerkhofs, M.J.M., de Voogd-Hamelink, A.M., Vosse J.P.M., de Wolff, C.J. (2001). Trendrapport vraag naar arbeid 2000. Tilburg: OSA. 
Frietman, J. \& Hövels, B. (1997). Zur Reform der beruflichen Bildung in den Niederlanden. In U. Beicht et al. (Eds.) Berufsperspektiven mit Lehre. Bielefeld: Bertelsmann.

Gerlach, K. \& Jirjahn, U. (2001). Employer provided further training: Evidence from German establishment data. Schmollers Jahrbuch, 121(2), 139-164.

Haak, C. (2003). Weiterbildung in kleinen und mittleren Betrieben. Ein deutsch-dänischer Vergleich. Mitteilungen aus der Arbeitsmarkt- und Berufsforschung, 36 (2), 166-186.

Kölling, A. (2000). The IAB-Establishment-Panel. Schmollers Jahrbuch, 120(2), 291-300.

Leuven, E. \& Oosterbeek, H. (2004). Evaluating the effect of tax deductions on training. Journal of Labor Economics, 22(2), 1-19.

Maes, M. (2004).Vocational education and training in the Netherlands: Short description. Luxembourg: EUR-OP.

Moraal, D. \& Schönfeld, G. (2005). Deutschland, Frankreich, Niederlande - drei Modelle der Finanzierung der betrieblichen Weiterbildung. In P. Faulstich \& M. Bayer (Eds.) Lerngelder: Für öffentliche Verantwortung in der Weiterbildung. Hamburg: VSA Verlag.

Nestler, K. \& Kailis, E. (2002). Continuing vocational training in the European Union and Norway: Statistics in Focus 3/2002. Luxembourg: Office for Official Publications of the European Communities.

Smits, W. \& Zwick, T. (2004). Why do business service firms employ fewer apprentices? A comparison between Germany and the Netherlands. International Journal of Manpower, 25(1), 36-54.

Waterreus, J.M. (2002). OE O-fondsen op herhaling. Stand van zaken scholingsfonden 2002. Amsterdam: Max Goote Kenniscentrum BVE.

Wooldridge, J.M. (2002). Econometric analysis of cross section and panel data. Cambridge: MIT Press. 


\section{Appendix - Wording of questions and coding of the indicators}

\section{IAB Establishment Panel:}

(1) Did your establishment offer further training in the first half of 1999? To be more precise: Did you release employees for the purpose of participating in internal or external further training measures or did you payat least a part of the further training costs?

If yes:

(2) For which of the following internal or external training measures did your establishment release staff or pay training costs?

A External training courses, seminars or workshops

B Internal training courses, seminars or workshops

C Further training on the job

D Participation in lectures, fairs etc.

E Job rotation

F Autonomous further training by means of media

G Quality circles etc.

$\mathrm{H}$ Other further training measures

(3) With respect to further training in the first half of 1999 , are you able to provide information on the number of individuals participating in further training or rather on the number of cases of participation? Please indicate the total number of participants (individuals or cases of participation) in the first half of 1999.

The indicator "Provision of further training" was coded 1 (Yes) if either question (2) A or question (2) B was answered affirmatively.

The indicator "Participation in further training" denotes the percentage of employees participating in further training corresponding to question (3). The cases of participation were transformed into the number of individuals participating in training.

\section{OSA Panel:}

(1a) Did it occur in 1998 that any employees of your establishment participate in internal further training measures?

(1b) How many employees participated in internal further training measures?

(2a) Did it occur in 1998 that any employees of your establishment participated in external further training measures?

(2b) How many employees participated in external further training measures?

(3) You have indicated the number of employees participating in internal training measures as well as the number of employees participating in external training measures. It can also happen that employees participate in both, internal and external training measures. How many employees have participated in internal as well as in external training measures in 1998 ?

The indicator "Provision of further training" was coded 1 (Yes) if either question (1a) or question (2a) or question (3) were answered affirmatively.

The indicator "Participation in further training" denotes the percentage of employees participating in further training corresponding to questions (1b, 2b, 3). 


\section{Appendix - Results of probit-analyses}

Table 5: Probit-estimates for having internal and / or external courses (West German establishments, 1999), 5 or more employees

\begin{tabular}{|c|c|c|c|}
\hline & $\begin{array}{l}\text { internal } \\
\text { courses }\end{array}$ & $\begin{array}{l}\text { External } \\
\text { courses }\end{array}$ & $\begin{array}{l}\text { internal or } \\
\text { external }\end{array}$ \\
\hline \multirow[t]{2}{*}{$\%$ age $<20$} & -0.031 & -0.457 & -0.078 \\
\hline & $(0.468)$ & $(0.414)$ & $(0.415)$ \\
\hline \multirow[t]{2}{*}{$\%$ age $20-30$} & 0.375 & -0.059 & 0.202 \\
\hline & $(0.271)$ & $(0.243)$ & $(0.249)$ \\
\hline$\%$ age $30-40$ & reference & reference & reference \\
\hline \multirow[t]{2}{*}{$\%$ age $40-50$} & -0.065 & -0.142 & -0.018 \\
\hline & $(0.267)$ & $(0.239)$ & $(0.245)$ \\
\hline \multirow[t]{2}{*}{$\%$ age $50-65$} & $-1.019 * * *$ & $-0.521^{* *}$ & $-0.667 * * *$ \\
\hline & $(0.247)$ & $(0.222)$ & $(0.230)$ \\
\hline \multirow[t]{2}{*}{$\%$ qualified workers } & $0.905 * * *$ & $0.586 * * *$ & $0.825 * * *$ \\
\hline & $(0.103)$ & $(0.099)$ & $(0.107)$ \\
\hline \multirow[t]{2}{*}{$\%$ female } & $0.499 * * *$ & $0.484 * * *$ & $0.680 * * *$ \\
\hline & $(0.114)$ & $(0.110)$ & $(0.119)$ \\
\hline \multirow[t]{2}{*}{$\%<15$ hours per week } & $-0.796 * * *$ & $-0.486^{* * *}$ & $-0.616 * *$ \\
\hline & $(0.247)$ & $(0.216)$ & $(0.220)$ \\
\hline \multirow[t]{2}{*}{$\%$ 15-24 hours per week } & -0.222 & $-0.356^{*}$ & -0.280 \\
\hline & $(0.221)$ & $(0.205)$ & $(0.215)$ \\
\hline \multirow[t]{2}{*}{$\%$ fixed term contracts } & -0.179 & -0.283 & -0.108 \\
\hline & $(0.231)$ & $(0.227)$ & $(0.238)$ \\
\hline \multirow[t]{2}{*}{$\%$ apprentices } & -0.146 & $1.470 * * *$ & $1.132 * * *$ \\
\hline & $(0.402)$ & $(0.392)$ & $(0.407)$ \\
\hline \multirow[t]{2}{*}{ Technological advanced (yes/ no) } & $0.251 * * *$ & $0.171 * * *$ & $0.186^{* * * *}$ \\
\hline & $(0.057)$ & $(0.054)$ & $(0.059)$ \\
\hline \multirow[t]{2}{*}{ Invested in ICT (yes/no) } & $0.293 * * *$ & $0.442 * * *$ & $0.435 * * *$ \\
\hline & $(0.055)$ & $(0.053)$ & $(0.057)$ \\
\hline \multirow[t]{2}{*}{ Expected labour shortages (yes/ no) } & 0.085 & $0.204 * * *$ & $0.208 * * *$ \\
\hline & $(0.055)$ & $(0.054)$ & $(0.059)$ \\
\hline \multirow[t]{2}{*}{ Churning rate } & $0.165^{* * *}$ & -0.012 & 0.048 \\
\hline & $(0.063)$ & $(0.064)$ & $(0.071)$ \\
\hline \multirow[t]{2}{*}{ Collective agreement (yes/no) } & $0.188 * * *$ & $0.171 * * *$ & $0.235 * * *$ \\
\hline & $(0.064)$ & $(0.062)$ & $(0.065)$ \\
\hline \multirow[t]{2}{*}{ Works council (yes/ no) } & $0.491 * * *$ & $0.234 * * *$ & $0.369 * * *$ \\
\hline & $(0.070)$ & $(0.070)$ & $(0.075)$ \\
\hline \multirow[t]{2}{*}{ Size $(\ln )$} & $0.376^{* * * *}$ & $0.314 * * *$ & $0.345 * * *$ \\
\hline & $(0.024)$ & $(0.024)$ & $(0.027)$ \\
\hline Sector dummies & yes & yes & yes \\
\hline \multirow{2}{*}{ Intercept } & $-2.824 * * *$ & $-1.714 * * *$ & $-2.060 * * *$ \\
\hline & $(0.202)$ & $(0.182)$ & $(0.196)$ \\
\hline $\mathrm{N}$ & 3671 & 3671 & 3671 \\
\hline
\end{tabular}


Table 6: Probit-estimates for having internal and/or external courses (Dutch establishments, 1999), 5 or more employees

\begin{tabular}{|c|c|c|c|}
\hline & $\begin{array}{l}\text { internal } \\
\text { courses }\end{array}$ & $\begin{array}{l}\text { External } \\
\text { courses }\end{array}$ & $\begin{array}{l}\text { internal or } \\
\text { external }\end{array}$ \\
\hline \multirow[t]{2}{*}{$\%$ age $<20$} & 0.081 & $-1.318 * *$ & -0.760 \\
\hline & $(0.541)$ & $(0.546)$ & $(0.589)$ \\
\hline \multirow[t]{2}{*}{$\%$ age $20-30$} & $0.500 *$ & -0.031 & 0.239 \\
\hline & $(0.298)$ & $(0.301)$ & $(0.325)$ \\
\hline$\%$ age $30-40$ & reference & reference & reference \\
\hline \multirow[t]{2}{*}{$\%$ age $40-50$} & 0.473 & 0.373 & 0.220 \\
\hline & $(0.310)$ & $(0.318)$ & $(0.341)$ \\
\hline \multirow[t]{2}{*}{$\%$ age $50-65$} & -0.051 & 0.052 & 0.003 \\
\hline & $(0.335)$ & $(0.355)$ & $(0.384)$ \\
\hline \multirow[t]{2}{*}{$\%$ qualified workers } & $0.338 * *$ & $0.570 * * *$ & $0.533 * * *$ \\
\hline & $(0.149)$ & $(0.158)$ & $(0.174)$ \\
\hline \multirow{2}{*}{$\%$ female } & $0.506^{* * * *}$ & 0.121 & 0.284 \\
\hline & $(0.194)$ & $(0.207)$ & $(0.230)$ \\
\hline \multirow[t]{2}{*}{$\%<12$ hours per week } & -0.294 & $-0.910 * * *$ & $-0.751 * *$ \\
\hline & $(0.332)$ & $(0.327)$ & $(0.348)$ \\
\hline \multirow[t]{2}{*}{$\%$ 12-23 hours per week } & -0.274 & $-0.512 *$ & -0.484 \\
\hline & $(0.271)$ & $(0.277)$ & $(0.302)$ \\
\hline \multirow[t]{2}{*}{$\%$ fixed term contracts } & -0.308 & 0.142 & -0.310 \\
\hline & $(0.367)$ & $(0.391)$ & $(0.415)$ \\
\hline \multirow[t]{2}{*}{$\%$ apprentices } & $1.317 * * *$ & $2.205^{* * * *}$ & $1.920 * * *$ \\
\hline & $(0.450)$ & $(0.614)$ & $(0.667)$ \\
\hline \multirow[t]{2}{*}{ Technological advanced (yes/ no) } & 0.018 & 0.013 & -0.047 \\
\hline & $(0.076)$ & $(0.086)$ & $(0.097)$ \\
\hline \multirow[t]{2}{*}{ New technology introduced (yes/ no) } & $0.267 * * *$ & $0.167 *$ & $0.229 * *$ \\
\hline & $(0.082)$ & $(0.099)$ & $(0.112)$ \\
\hline \multirow[t]{2}{*}{ Difficulties to fill vacancies (yes/no) } & 0.007 & $0.244 * * *$ & $0.170^{*}$ \\
\hline & $(0.082)$ & $(0.089)$ & $(0.099)$ \\
\hline \multirow[t]{2}{*}{ Churning rate } & 0.300 & 0.256 & $0.444 *$ \\
\hline & $(0.201)$ & $(0.213)$ & $(0.251)$ \\
\hline \multirow[t]{2}{*}{ Collective agreement (yes/ no) } & 0.058 & -0.035 & -0.008 \\
\hline & $(0.135)$ & $(0.147)$ & $(0.160)$ \\
\hline \multirow[t]{2}{*}{ Works council (yes/ no) } & 0.084 & 0.120 & 0.134 \\
\hline & $(0.093)$ & $(0.098)$ & $(0.109)$ \\
\hline \multirow[t]{2}{*}{ Size $(\ln )$} & $0.475 * * *$ & $0.342 * * *$ & $0.492 * * *$ \\
\hline & $(0.035)$ & $(0.043)$ & $(0.056)$ \\
\hline Sector dummies & yes & yes & yes \\
\hline \multirow[t]{2}{*}{ Intercept } & $-2.489 * * *$ & $-0.897 * * *$ & $-1.304 * * *$ \\
\hline & $(0.288)$ & $(0.312)$ & $(0.351)$ \\
\hline $\mathrm{N}$ & 1492 & 1492 & 1492 \\
\hline
\end{tabular}

$* * * / * * / *$ denotes significance at the $1 \%-/ 5 \%-/ 10 \%$-level. Source: IAB, OSA 